\title{
Correction to: Promotor analysis of ESR1 in endometrial cancer cell lines, endometrial and endometriotic tissue
}

\author{
Vanessa Todorow $^{1} \cdot$ Martina Rahmeh $^{1} \cdot$ Simone Hofmann $^{1} \cdot$ Verena Kirn $^{2} \cdot$ Sven Mahner $^{1} \cdot$ Udo Jeschke $^{1,3}$ (D) \\ Viktoria von Schönfeldt ${ }^{1}$
}

Published online: 8 June 2018

○) Springer-Verlag GmbH Germany, part of Springer Nature 2018

\section{Correction to: Arch Gynecol Obstet (2017) 296:269-276 https://doi.org/10.1007/s00404-017-4405-x}

In the original publication of the article, the name of first author was misspelled. The correct name has been copied below:

Vanessa Todorow

The original article can be found online at https://doi.org/10.1007/ s00404-017-4405-x.

Udo Jeschke

udo.jeschke@med.uni-muenchen.de

1 Klinik und Poliklinik für Frauenheilkunde und Geburtshilfe, Klinikum der Universität München, Munich, Germany

2 Klinik und Poliklinik für Frauenheilkunde, Universitätsklinikum Köln, Cologne, Germany

3 Department of Obstetrics and Gynecology,

Ludwig-Maximilians-University, Maistrasse 11,

80377 Munich, Germany 